\title{
Applicability of Building Information Modelling (BIM) in the Sustainable Design of Commercial and Office Buildings. A Case Study from Tehran, Iran
}

\author{
Behrouz NEMATI', Babak AMINNEJ AD ${ }^{2 *}$, Alireza LORK ${ }^{3}$ \\ ${ }^{*}$ Corresponding author \\ ${ }^{1}$ Department of Civil Engineering, Kish International Branch, Islamic Azad University, Kish Island, IRAN \\ ${ }^{2}$ Department of Civil Engineering, Roudehen Branch, Islamic Azad University, Tehran, IRAN \\ ${ }^{3}$ Department of Civil Engineering, Safadasht Branch, Islamic Azad University, Tehran, IRAN \\ E-mail: aminnejad@riau.ac.ir
}

DOI: $10.24193 /$ J SSPSI.2020.6.05

https:// doi.org/ 10.24193/J SSPSI.2020.6.05

Ke y w o r d s: energy efficiency, Building Information Modelling (BIM), commercial and office buildings, greenhouse gas emission

\begin{abstract}
A B S T R A C T
Preventing energy loss in commercial and office buildings can increase economic benefits, and will help protect the environment by reducing the emissions of greenhouse gases. The mentioned parameters are among the main pillars of sustainability and are also the most important items emphasized in EU 2030 sustainability goals. Accordingly, governments and researchers have paid enormous attention to find effective ways to manage and sustain the energy use in such buildings. In this regard, energy analysis tools have been widely used by designers to enhance energy efficiency of buildings. Building Information Modeling (BIM) enables users to evaluate different design alternatives and select the best critical energy strategies and systems in the conceptual design phase of any proposed projects. The purpose of this study is to demonstrate the application of the BIM in assessing the effect of different methods on reducing energy consumption, energy loss, and greenhouse gas emissions in the early stages of the building design process. Indeed, BIM can offer the best option(s) prior to make the decisions about how to construct buildings by analyzing various methods to obtain the required information. Results indicated that in the project under study, the application of inside insulators can reduce the consumption of electricity and gas by $4.76 \%$ and $11.06 \%$, respectively, as well as the $\mathrm{CO}_{2}$ emissions by $10.75 \%$. The use of outside insulation was also illustrated to be able to reduce electricity and gas consumption by $7.17 \%$ and $30.48 \%$, respectively and $\mathrm{CO}_{2}$ emissions by $29.31 \%$.
\end{abstract}

\section{INTRODUCTION}

Urbanization and the ongoing demand for energy on one hand, and the associated economic and environmental consequences on the other have motivated researchers to develop some effective solutions for energy efficiency in buildings ( $\mathrm{J}$ ahanshahi et al., 2019; Omer, 2008). The increasing trend of using of fossil fuels, together with the environmental consequences attributed to the use of conventional resources such as pollution and global warming, on one hand, along with population growth and the energy insecurity triggered by political and economic effects, are some of the most important related issues at global scale (Höök and Tang, 2013). Therefore, one of the most important goals of researchers has been to strive for environmental goals in energy production and moving towards sustainable development in various fields (Davarazar et al., 2019, 2020; Kamali et al., 2019; Zandi et al., 2019). Globally, more than $50 \%$ of the total population are living in the cities (Kullman et al., 2016). In Europe, about $40 \%$ of energy consumption and about 
$36 \%$ of greenhouse gases are associated with the cities' mainly buildings (Campillo et al., 2016). In this situation, enhancing energy efficiency and moving towards achieving sustainable development goals (Kamali, 2020), as well as avoiding energy waste and promoting renewable energy production and consumption are among the attractive strategies to overcome the existing issues related to energy consumption and efficiency in buildings (FernándezMaldonado et al., 2016; Kaygusuz, 2009).

When integrated with the building design process the estimation of energy consumption can greatly contribute to prevent energy loss and make energy consumption in buildings sustainable. Building information modelling (BIM) is one of the most appropriate tools that can be employed to help in this regard (Jalaei and Jarde, 2014). BIM provides a graphical data and information management system with a detailed description of the construction project based on the modelling and simulations performed. Also, all of the building materials, namely smart objects in the design process can be subject of investigation to depict the disadvantages and barriers related to the construction of the building, and can assist in saving time and financial resources (Garyaeva, 2018; Reizgevi cius and Ustinovi cius, 2018; Zhao et al., 2017). BIM has been initially developed in the fast-growing building industry in advanced countries and its benefits have been well recognized (Nemati et al., 2020). However, this tool has not been yet fully commercialized all over the world, especially in developing countries. In this regard, various studies have been carried out to overcome the existing barriers (Nemati et al., 2020; Kaneta et al., 2017). Also, a number of researchers are currently investigating the way of promoting BIM for real applications (Migilinskas et al., 2013; Kaneta et al., 2017), especially for energy consumption simulation purposes (Choi et al., 2019; Kamel and Memari, 2019; Pruvost and Scherer, 2017). The results of such studies have indicated that BIM can be efficiently used to reduce energy consumption and construction costs and to decrease the time of constructing a building. (Ham and Golparvar-Fard, 2015). For example, Lin et al. (2019) studied the green BIM. They simulated the Xiedian Central Public Market by Revit Software and considered variables such as solar radiation, natural daylighting, indoor and outdoor airflow conditions, etc. They demonstrated that energy consumption can be efficiently reduced by improving the thermal insulation of the roof and the building envelope (with analysis on the important and main spaces in terms of energy consumption and installing crystalline solar panels on the roof). In another study, Kim et al. (2016) investigated the condition of windows and their impact on energy consumption. Their simulation indicated that when windows are located in the middle height, the lowest load is needed, and that if 42 windows are positioned on the east side it affects the total energy load the most.

Considering the case of commercial and office buildings, the evaluation and calculation of energy consumption with the aim of reducing energy will have a major impact on the environment and economy of each country, because, the energy consumption of these buildings is highly significant (Roth et al., 2002). The purpose of this study is to perform an estimation of the reduction in energy consumption and carbon dioxide emissions in commercial and office buildings in Iran, Tehran by using BIM to help reducing energy consumption during the design process, and to select the best methods and materials based on the results achieved prior to the construction of buildings.

\section{METHODOLOGY}

\subsection{General considerations}

BIM can create intelligent connections between different design components and enables the examination of different varieties and audit scenarios (Dincer, 2000). The application of different insulation methods to reduce energy consumption (Piselli et al., 2019; Wi et al., 2019), and changing the thickness of the insulation used in the walls of the buildings are some of the existing scenarios in this regard. To reach the sustainable design goals in this area, BIM can be used to analyze the possible scenarios much faster than using traditional methodologies. Measures such as the window orientation, building mass, maximum utilization of daylight, and the possibility of renewable energy generation, as well as the application of sustainable building materials (Bryde et al., 2014) are examples of criteria that can be analysed using BIM. In order to develop a building information modelling framework to be employed (for instance) in building energy auditing, the following steps have been recommended in the literature (Li et al., 2012).

a). Gathering and documentation of the basic building information and completing the related energy auditing forms. energy bills.

b). Calculating the building load factor using

c). Modelling and determining the building load according to the requirements of the applicable legislation (here, section 19 of the Iranian Building Regulations (Fayaz and Kari, 2009)).

d). Identification of energy-saving opportunities and economic evaluation of energy-saving strategies (Egwunatum et al., 2016).

When auditing a particular building regarding energy efficiency (Lin et al., 2019), criteria such as climatic conditions and geographical location of the building, materials used in the outer shell and the walls, architectural and structural properties, central building 
installations, heating, cooling, air conditioning and lighting, as well as consumables and accessories and office equipment are being considered. To design a new building project using BIM requires information regarding building location, energy sources conditions, energy prioritization of modelling and optimization solutions, as well as budgeting (Becerik-Gerber et al., 2012). It is worth mentioning that energy auditing of a building is considered to be some kind of refurbishment of the building, so an architect and an energy auditor are needed to make the best collaborative decisions (Chong et al., 2017).

Various software is used in BIM such as Sketchup, Auto Desk Revit, Archicad, Tekla Structure, Bentley, Design Builder, Green Building Studio, Bim 360, etc. (Adami et al., 2017; Khaddaj and Srour, 2016; Providakis et al., 2019). But in the field of building energy analysis, Auto Desk Revit and Design-Builder softwares are of high accuracy in the building designing process and delivering the results (Bahar et al., 2013).

After acquiring all of the information, the building is modelled using Revit software (version 2019.2.2 in this study). Data regarding walls, openings, lighting, etc. is also included in this analysis (Kim et al., 2016). Revit is further utilized after data entry (which includes all the design details), to design spaces and define thermal zones (Ugliotti et al., 2016). Therefore, to simplify the energy modelling process, it is assumed, there is not another building around the building under study (Fig. 1).

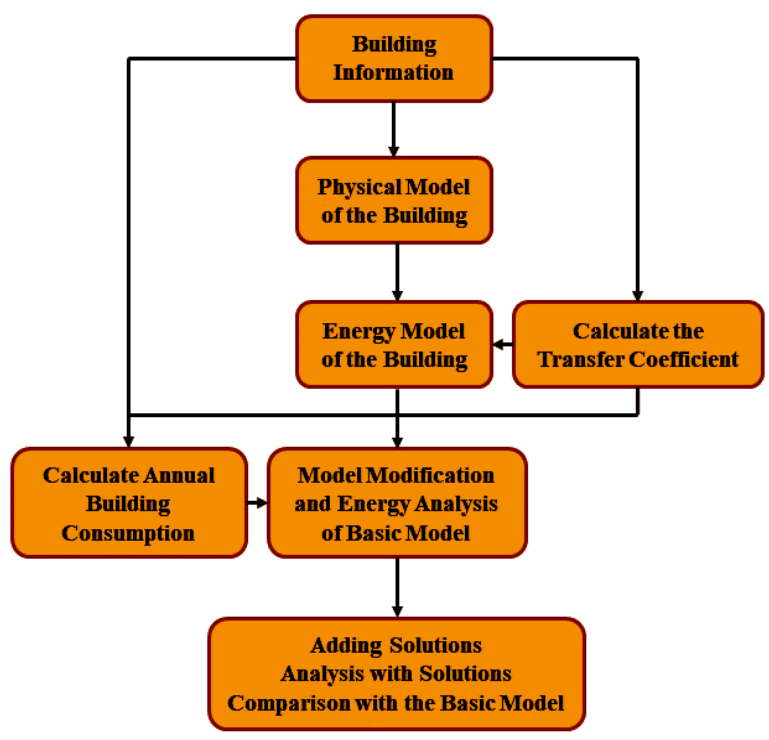

Fig. 1. A schematic of the present research design.

Design-Builder software (version 6.1.0.6 in this study) is also used to check the following parameters: the amount of air leakage from the walls, the detailed specifications of the windows, etc.; afterwards, the required modifications are applied accordingly. The next step is to compare the simulation results with the real situation conditions to validate the method employed. Validation is normally performed in three ways, namely comparative, experimental and analytical. After ensuring the accuracy of simulation results, the feasible solutions for buildings are investigated and the investment return rate is assessed. Also, by considering the carbon dioxide emission criterion, the emission rate of the commercial and office units can be obtained (Kurian et al., 2016).

Given that office and commercial buildings are very important in terms of energy consumption (PérezLombard et al., 2008), these buildings were selected for this study.

\subsection{Case study}

For the present study, a building located in Tehran was selected for the energy audit process according to the mentioned methodology (section 2.1). The studied building consists of 8 floors with a commercial ground floor. First to eighth floors are occupied by the offices and 2 underground levels were designed for car parking (Fig. 2).

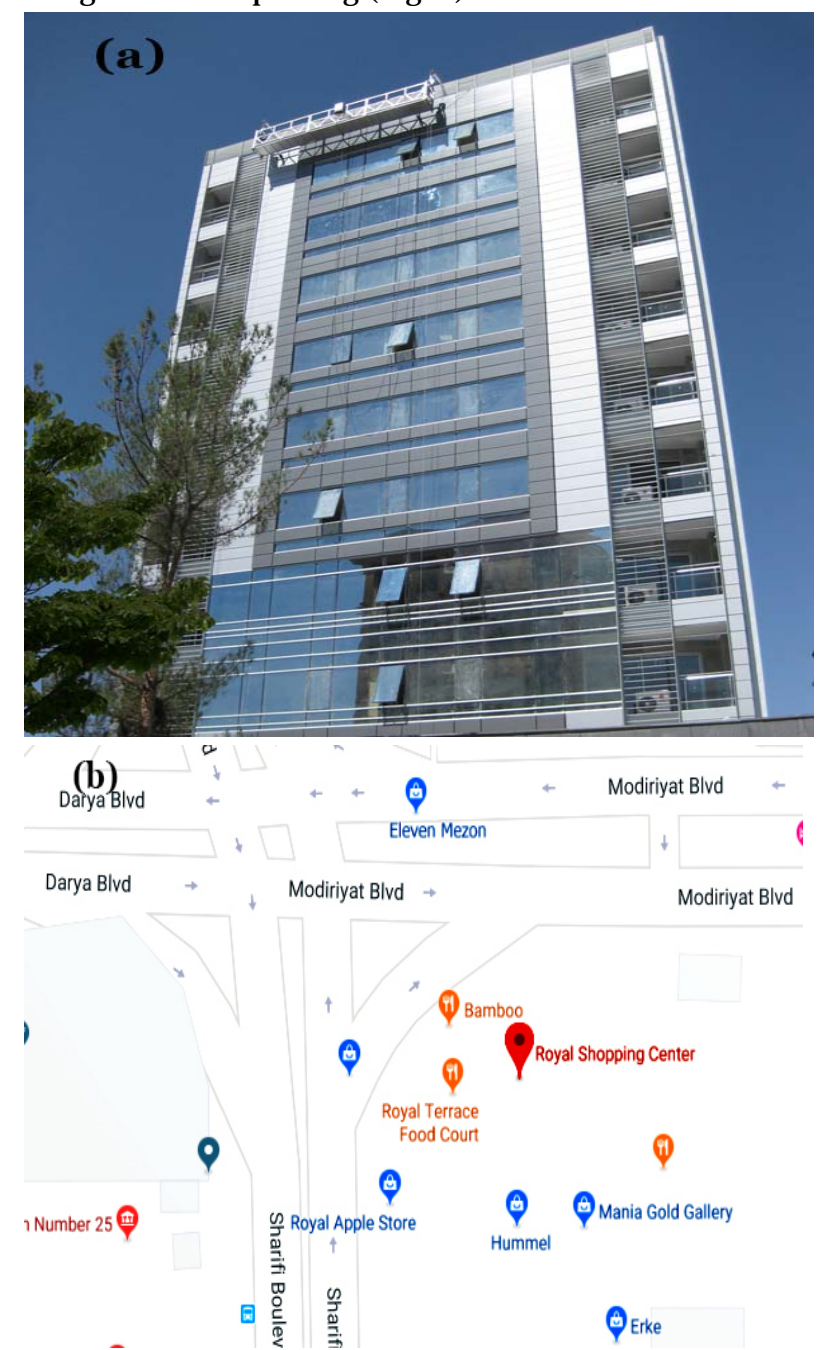
of the building.

Fig. 2. (a) South facade of the building, (b) Location 
The first step was to model the commercial and office units using Autodesk Revit software according to the existing building plans (Fig. 3).
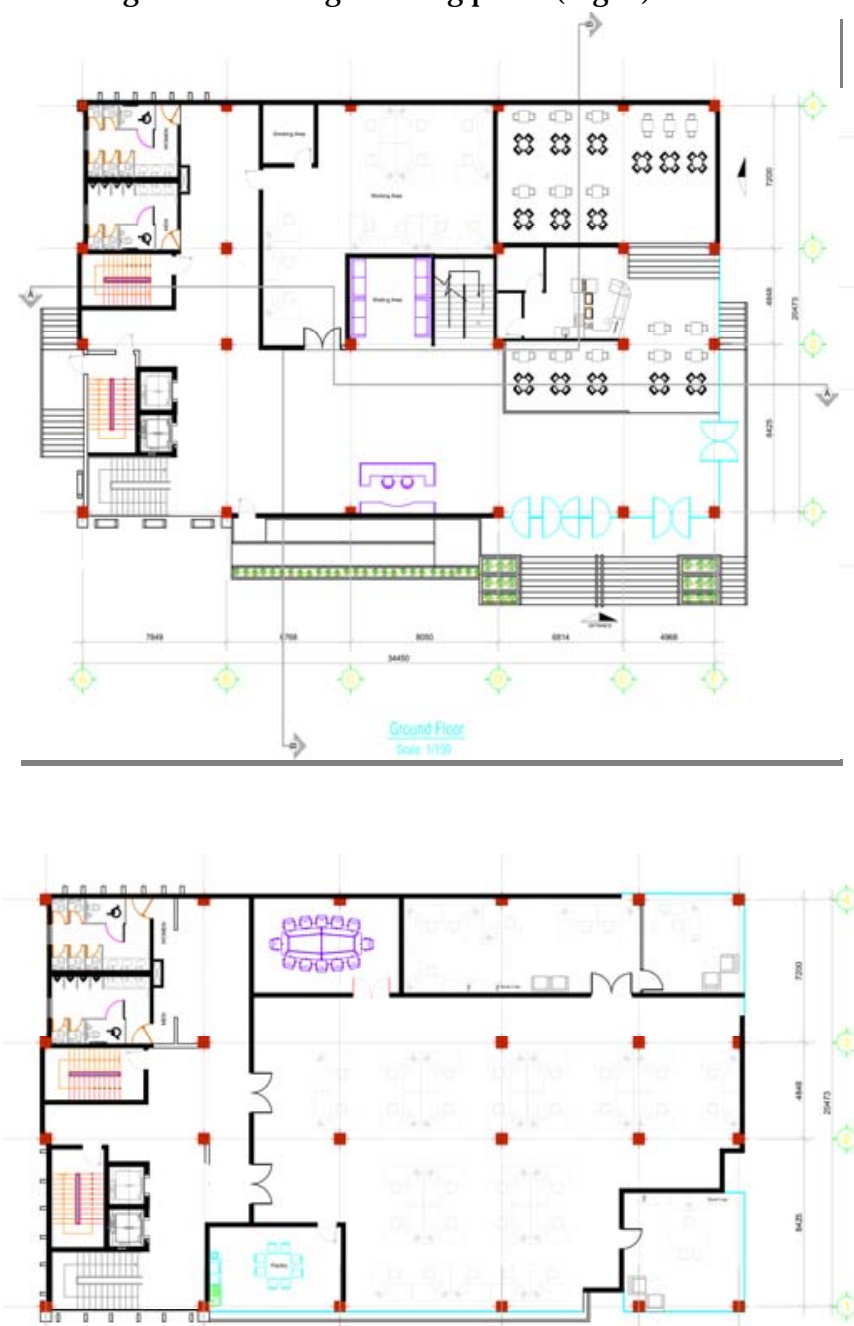

Fig. 3. 2D plane of the building.

The thermal conductivity of the doors, glasses and insulations in Autodesk Revit software were determined, followed by the validation of the simulation results using Design Builder software. The
Then, the technical documents of these units, such as plans and user status, are obtained from the software output.
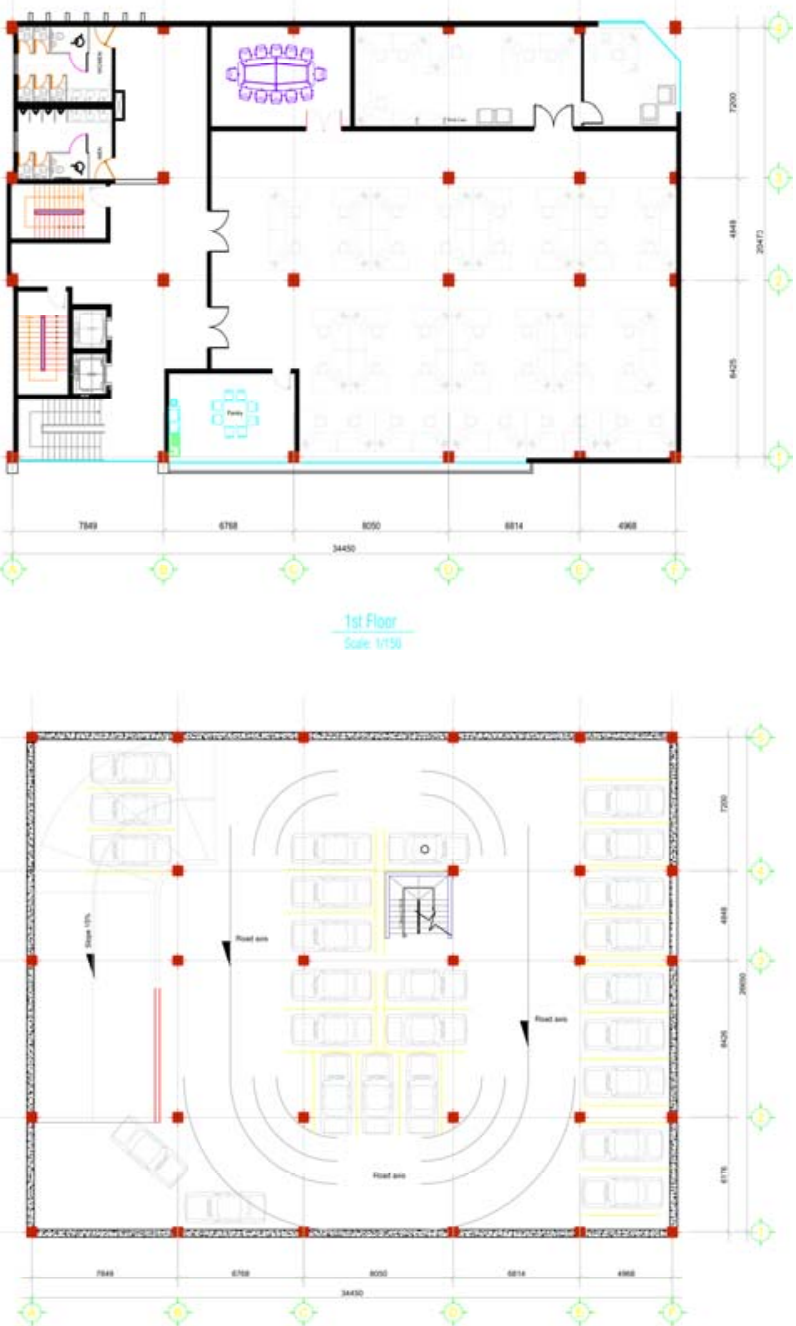

specifications of the building, along with the functionally loaded building coefficient, in accordance with section 19 of the Iranian Building Regulations (Fayaz and Kari, 2009) are indicated in Table 1.

Table 1. Design heat transfer coefficient and building reference by functional method.

\begin{tabular}{|c|c|c|c|c|c|c|c|}
\hline No. & Building Details & Area $\left(\mathrm{m}^{2}\right)$ & $\mathrm{DF}^{1}$ & $\underline{\mathbf{U}} \mathbf{H T F}^{2}$ & ${\underline{\text { IBR }^{3}}}_{\text {HTF }^{2}}$ & $\underline{\mathbf{H}^{\wedge}} \mathbf{H T F}^{2}$ & $\underline{\mathbf{H}} \mathbf{H T F}^{2}$ \\
\hline 1 & Roof & 838 & 1 & 0.534 & 0.59 & 61.06 & 46.75 \\
\hline 2 & Exterior walls & 1917.50 & 1 & 1.751 & 1.12 & 19.8 & 27.21 \\
\hline 3 & Windows & 132.40 & 1 & 5.302 & 5.63 & 45.76 & 42.31 \\
\hline 4 & Glass Doors & 88 & 1 & 5.105 & 5.63 & 26.95 & 25.41 \\
\hline 5 & Walls (around the staircase) & 96.40 & 0.43 & 2.423 & 0.74 & 0.612 & 16.02 \\
\hline 6 & Walls (around the elevator) & 104.30 & 0.094 & 2.423 & 0.74 & 0.136 & 37.52 \\
\hline 7 & Walls (around public place) & 182.40 & 0.351 & 2.423 & 0.74 & 0.425 & 19.03 \\
\hline 8 & Main Doors & 47.60 & 1 & 5.92 & 4.32 & 4.63 & 0 \\
\hline
\end{tabular}


The consumption of gas and electricity over a period of 5 years (2014 till 2018) according to the bills issued for the building were extracted in order to compare the results achieved from the simulation using BIM with the real energy consumed using the DesignBuilder software (Table 2).

Table 2. Energy consumed by the building (based on energy bills in 5 years).

\begin{tabular}{|l|rrrr}
\multicolumn{1}{c|}{ Energy } & \multicolumn{1}{c}{ Consumption } & Energy Cost $(€)$ & \% & Annual consumption (Average) \\
\hline Electricity & $34,666,667(\mathrm{kwh})$ & 110,933 & 37 & $6,933,333.4(\mathrm{kwh})$ \\
Gas & $7,209,000\left(\mathrm{~m}^{3}\right)$ & 189,837 & 63 & $1,441,800\left(\mathrm{~m}^{3}\right)$ \\
Total & & 300,770 & 100 &
\end{tabular}

According to the existing data (Tables 1 and 2), the unit was modelled and simulated using both Autodesk-Revit and Design-Builder and the initial model was calibrated. Two adjacent neighbouring spaces were also considered as uncontrolled spaces to be audited with a confidence factor. In addition, all components such as floors, walls and ceilings were modelled with the defined thermal properties for the materials used.

After modelling the components and defining the thermal zones, the angle of building orientation to the north, as well as the location of the building in the software were determined. In this step, the software needs to know the details of the materials used in the building and the climatic conditions of the building for a more accurately analysis. The Insight 360 plugin (Ghobad, 2018) was also used to build the energy models based on the existing data. Once the energy model was designed, the output was imported into Design Builder software for further analysis.

\section{RESULTS AND DISCUSSION}

After performing basic modelling, results were compared with the existing situation to ensure the accuracy of the results achieved. Then, by manipulation of one parameter while keeping others constant, energy efficiency optimization in the studied building was explored in a numerical way. Two main approaches were applied to this end including "inside insulation" and "outside insulation". The Design Builder software was used to simulate the building in terms of various points of view such as, materials applied, heating and cooling systems, architecture, daylight, ventilation, etc. to provide multiple solutions for designers.

The selected solutions in this process will be subjected to: a) a detailed review, based on the existing by-laws in Iran to meet the requirements of the study area, and b) an examination of solutions that are costeffective and fully operational. The results achieved regarding the final analysis performed are shown in Tables 3 and 4 .
Table 3. The energy consumption of the studied building estimated using inside insulation (based on energy bills in 5 years).

\begin{tabular}{|l|l|r|r|}
\hline \multicolumn{2}{|c|}{ Saving method: inside insulation } & \multicolumn{1}{c|}{$\begin{array}{c}\text { Effect } \\
(\%)\end{array}$} \\
\hline \multirow{3}{*}{$\begin{array}{l}\text { Electricity } \\
\text { (kwh) }\end{array}$} & Before & $6,933,333.40$ & \\
\cline { 2 - 3 } & After & $6,603,168.06$ & 4.762 \\
\cline { 2 - 3 } & Decrease & $330,165.34$ & \\
\hline \multirow{2}{*}{ Gas ${\left(\mathbf{m}^{3}\right)}^{\mathbf{3}}$} & Before & $1,441,800.00$ & \multirow{2}{*}{11.061} \\
\cline { 2 - 3 } & After & $1,282,322.50$ & \\
\cline { 2 - 3 } & Decrease & $159,477.50$ & \\
\hline \multirow{2}{*}{$\begin{array}{l}\mathbf{C O} \\
\text { emissions } \\
\text { (kg) }\end{array}$} & Before & $743,121.00$ & \multirow{2}{*}{10.746} \\
\cline { 2 - 3 } & After & $663,265.22$ & \\
\cline { 2 - 3 } & Decrease & $79,855.78$ & \\
\hline
\end{tabular}

Table 4. An estimation of the energy consumption by using the outside insulation (based on energy bills in 5 years).

\begin{tabular}{|c|c|c|c|}
\hline \multicolumn{3}{|c|}{ Saving method: outside insulation } & $\begin{array}{c}\text { Effect } \\
(\%)\end{array}$ \\
\hline \multirow{3}{*}{$\begin{array}{l}\text { Electricity } \\
\text { (kwh) }\end{array}$} & Before & $6,933,333.40$ & \multirow{3}{*}{7.168} \\
\hline & After & $6,436,352.06$ & \\
\hline & Decrease & $496,981.34$ & \\
\hline \multirow{3}{*}{ Gas $\left(\mathbf{m}^{3}\right)$} & Before & $1,441,800.00$ & \multirow{3}{*}{30.478} \\
\hline & After & $1,002,368.20$ & \\
\hline & Decrease & $439,431.80$ & \\
\hline \multirow{3}{*}{$\begin{array}{l}\mathrm{CO}_{2} \\
\text { emissions } \\
(\mathrm{kg})\end{array}$} & Before & 743121.00 & \multirow{3}{*}{29.312} \\
\hline & After & $525,297.37$ & \\
\hline & Decrease & $217,823.63$ & \\
\hline
\end{tabular}

In addition, the comparative graphs concerning the application of inside insulation and outside insulation achieved using BIM method are illustrated in Figure 4.

According to the results presented in Table 3, the application of inside insulators can reduce electricity and gas consumption by $4.76 \%$ and $11.06 \%$, respectively, and also $\mathrm{CO}_{2}$ emissions by $10.75 \%$. However, the use of outside insulation was indicated to have a greater impact on the reduction of both 
electricity and gas consumption (by $7.17 \%$ and $30.48 \%$, respectively) and also the $\mathrm{CO}_{2}$ emission by $29.31 \%$.

(a)

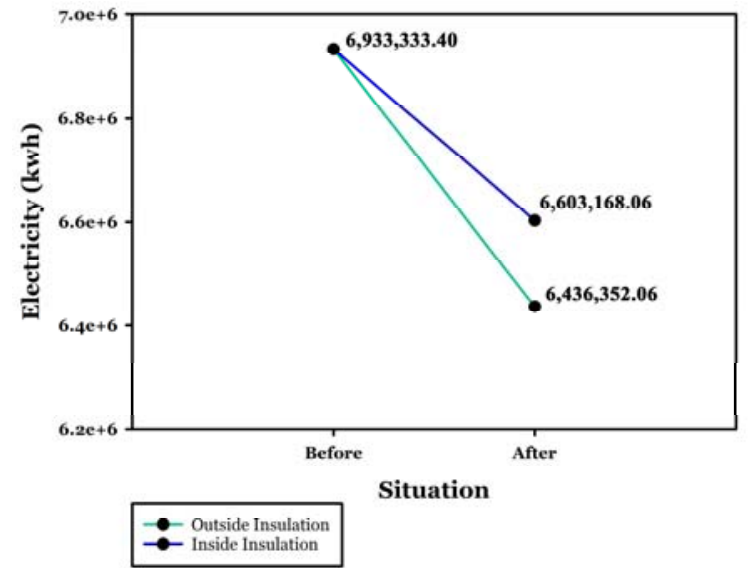

(b)

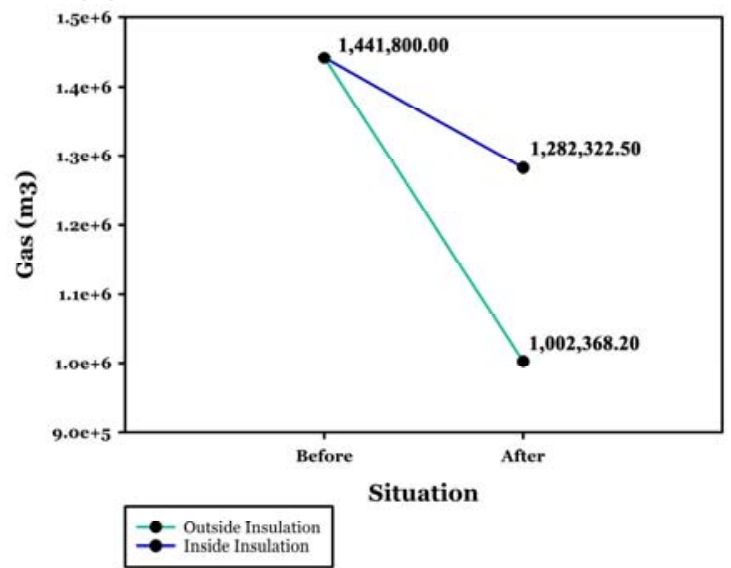

(c)

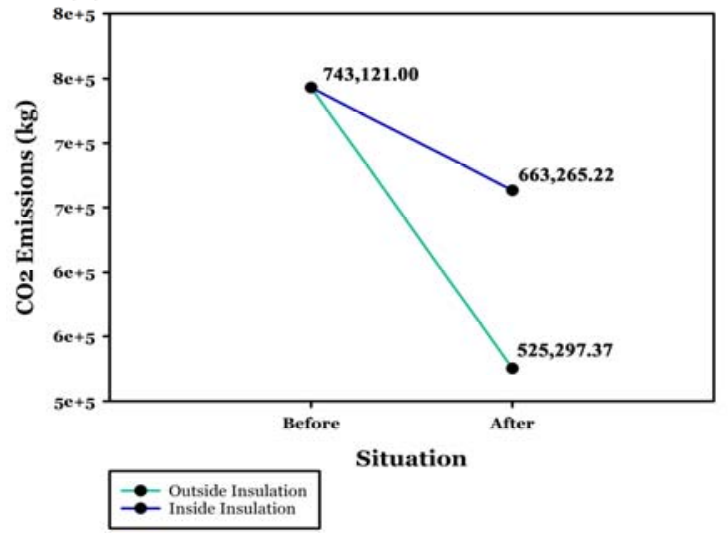

Fig. 4. Comparative results on the reduction of the electricity consumption (a), gas consumption (b), and $\mathrm{CO}_{2}$ emissions (c).

As can be observed from the results achieved in this study, the use of outside insulation had greater effects in terms of both energy consumption and greenhouse gas emissions, compared to those using the inside insulation approach. There are some similar results in the literature. For instance, Cheng et al. (2017) used a typical meteorological year (TMY) to compare the efficiency of the inside and outside 46 insulation in the case of a bedroom in Shanghai. They indicated that outside insulation was more efficient in energy saving that inside insulation. Meng et al. (2018) also indicated the better performance of the outside insulators for wall thermal insulation, compared to inside insulation. Results of this study also indicated that forecasting energy consumption by considering the construction conditions during the design stage can help to choose the best materials and construction methods for a given project as also emphasized by Zardo et al. (2019). In addition, considering the results achieved in this study, it can be concluded that the energy audit process using BIM is more accurate and precise than those can be achieved using traditional approaches in the energy audit process, fact that is also supported by the existing literature (Abanda and Byers, 2016). It has to be mentioned that in the case of conventional approaches, complex mathematical calculations are required to determine the effectiveness of each solution proposed by the method. Using BIM methodology, simulation and analysis of data are performed simultaneously, which can speed the process of modelling up in order to achieve the optimum results and outputs. Also, it provides the possibility to adjust any baseline data while modelling or even implementing any possible solutions and to check the results achieved in each phase of the project. In the conventional methods, changing the basic data necessitates repeating all simulations from the scratch. Moreover, using BIM method, it is possible to examine the effect of several solutions simultaneously on the overall buildings energy consumption. Hence, at each stage of the audit process, the designer can monitor the effects of several solutions on the outputs.

\section{CONCLUSION}

Sustainable design possibilities of an existing commercial and office building in Tehran, Iran were proposed using BIM methodology. An initial modelling was performed in Autodesk Revit software and then the Design-Builder software was utilized for the analysis of the energy consumption. After obtaining the details of consumption and manufacturing, the building and its proximity area were precisely modelled using the Autodesk Revit 2019.2 software by incorporating the actual thermal properties of the materials, doors and windows. Then, the energy model was designed for further analysis. Comparing the results obtained from the software and the current situation of the building, it was found that by using internal insulation of the building, electricity consumption can decrease by $4.76 \%$, gas consumption by $11.06 \%$ and carbon dioxide emission by $10.75 \%$. Also, using the outside insulation approach, a decrease in electricity consumption by $7.17 \%$, gas consumption by $30.48 \%$ and carbon dioxide emissions by $29.31 \%$ were also achieved. 
Applicability of Building Information Modelling (BIM) in the Sustainable Design of Commercial and Office Buildings. A Case Study from Tehran, Iran

J ournal of Settlements and Spatial Planning, Special Issue, no. 6 (2020) 41-49

Multi-Criteria Spatial Decision Support Systems for Sustainable Development

\section{REFERENCES}

Abanda F. H., Byers L. (2016), An investigation of the impact of building orientation on energy consumption in a domestic building using emerging BIM (Building Information Modelling). Energy, 97, 517-527. DOI: https://doi.org/ 10.1016/j.energy.2015. 12.135.

Adami A., Scala B., Spezzoni A. (2017), Modelling and accuracy in a bim environment for planned conservation: The apartment of troia of Giulio Romano. International Archives of the Photogrammetry, Remote Sensing and Spatial Information Sciences - ISPRS Archives, 42(2W3), 17- 23. DOI:https:// doi.org/ 10.5194/ isprs-archives-XLII-2-

W3-17-2017

Bahar Y., Pere C., Landrieu J., Nicolle C. (2013), A Thermal Simulation Tool for Building and Its Interoperability through the Building Information Modeling (BIM) Platform. Buildings, 3(2), 380-398. DOI:https:// doi.org/ 10.3390/ buildings3020380

Becerik-Gerber B., J azizadeh F., Li N., Calis G. (2012), Application areas and data requirements for BIM-enabled facilities management. Journal of Construction Engineering and Management, 138(3), 431-442. DOI: https:// doi.org/10.1061/ (ASCE)CO. 1943-7862.0000433

Bryde D., Broquetas M., Volm J. M. (2014), The project benefits of Building Information Modelling (BIM). International J ournal of Project Management, 31 (June 2011), 971-980. DOI: https://dx.doi.org/ 10.1016/j.jproman.2012.12.001

Campillo J., Vassileva I., Dahlquist E., Lundström L. (2016), Beyond the Building Understanding Building Renovations in Relation to Urban Energy Systems. Journal of Settlements and Spatial Planning, 5, 31-39. DOI: https://doi.org/ 10. 19188/ 04J SSPSI052016

Cheng F., Zhang X., Su X. (2017), Comparative assessment of external and internal insulation for intermittent air-conditioned bedrooms in Shanghai. Procedia Engineering, 205, 50-55. DOI: https://doi. org/ 10.1016/j.proeng.2017.09.933

Choi J. W., Jun Y. J., Yoon J. H., Song Y. H., Park K. S. (2019), A study of energy simulation integrated process by automated extraction module of the BIM geometry module. Energies, 12(13), 2461. DOI: https:/ / doi.org/ 10.3390/ en12132461

Chong H. Y., Lee C. Y., Wang X. (2017), A mixed review of the adoption of Building Information Modelling (BIM) for sustainability. J ournal of Cleaner Production, 142, 4114-4126. DOI: https://doi.org/ 10.1016/j.jclepro.2016.09.222

Davarazar M., J ahanianfard D., Sheikhnejad Y., Nemati B., Mostafaie A., Zandi S., ... Aminabhavi T. M. (2019), Underground carbon dioxide sequestration for climate change mitigation - A scientometric study. Journal of $\mathrm{CO} 2$ Utilization, 33(May), 179-188. DOI: https:// doi.org/ 10.1016/ j.jcou.2019.05.022

Davarazar M., Mostafaie A., Jahanianfard D., Davarazar P., Ghiasi S. A. B., Gorchich M., ... Aminabhavi T. M. (2020), Treatment technologies for pharmaceutical effluents-A scientometric study. J ournal of Environmental Management, 254(J anuary), 109800. DOI: https:// doi.org/ 10.1016/j.jenvman. 2019.109800

Dincer I. (2000), Renewable energy and sustainable development: A crucial review. Renewable \& Sustainable Energy Reviews, 4(2), 157- 175. DOI: https:// doi.org/ 10.1016/ S1364-0321(99)00011-8

Egwunatum S., Joseph-Akwara E., Akaigwe R. (2016), Optimizing Energy Consumption in Building Designs Using Building Information Model (BIM). Slovak J ournal of Civil Engineering, 24(3), 19- 28. DOI: https:// doi.org/ 10.1515/ sjce-2016-0013

Fayaz R., Kari B. M. (2009), Comparison of energy conservation building codes of Iran, Turkey, Germany, China, ISO 9164 and EN 832. Applied Energy, 86(10), 1949- 1955. DOI: https:// doi.org/ 10.1016/j.apenergy. 2008.12.024

Fernández-Maldonado A. M., Méndez P. L., Vieites E. (2016), Planning for Energy Efficiency in a Historic City. The Case of Santiago de Compostela, Spain. Journal of Settlements and Spatial Planning, 5, 53- 56. DOI: https:// doi.org/ 10.19188/ 06J SSPSI 052016

Garyaeva V. (2018). Formation of competitive skills of engineers in the field of BIM technologies. MATEC Web of Conferences 170, 01077, 1-4. DOI: https://doi.org/ 10.1051/matecconf/201817001077

Ghobad L. (2018), Daylighting and Energy Simulation Workflow in Performance- Based Building Simulation Tools. 2018 Building Performance Analysis Conference and SimBuild Co-Organized by ASHRAE and IBPSAUSA, 382- 389.

Ham Y., Golparvar-Fard M. (2015), Mapping actual thermal properties to building elements in gbXMLbased BIM for reliable building energy performance modeling. Automation in Construction, 49, 214-224. DOI: https:// doi.org/ 10.1016/j.autcon. 2014.07.009

Höök M., Tang X. (2013), Depletion of fossil fuels and anthropogenic climate change-A review. Energy Policy, 52, 797-809. DOI: https://doi.org/ 10.1016/ j.enpol.2012.10.046

Jahanshahi A., Jahanianfard D., Mostafaie A., Kamali M. (2019), An Auto Regressive Integrated Moving Average (ARIMA) Model for prediction of energy consumption by household sector in Euro area. 7(December 2018), 151-164. DOI:https:// doi.org/ 10.3934/ energy.2019.2.151

Jalaei F., Jarde A. (2014), Integrating Building 
Information Modeling (Bim) And Energy Analysis Tools With Green Building Certification System To Conceptually Design Sustainable Buildings. Journal of Information Technology in Construction, 19(6), 494519. DOI:https:// doi.org/ 10.3109/ 17549507.2013. 862857

Kamali M. (2020), Guest Editorial An Opinion on Multi-Criteria Decision-Making Analysis for Sustainability-Based Spatial Planning Practices. Time to Improve? in press. DOI:https:// doi.org/ 10.24193/ JSSPSI.2020.6.01

Kamali M., Suhas D. P., Costa M. E., Capela I., Aminabhavi T. M. (2019), Sustainability considerations in membrane-based technologies for industrial effluents treatment. Chemical Engineering J ournal, 368(February), 474- 494. DOI:https:// doi.org/ 10.1016/j.cej.2019.02.075

Kamel E., Memari A. M. (2019), Review of BIM 's application in energy simulation: Tools, issues and solutions. Automation in Construction, 97(J une 2017), 164- 180. DOI:https:// doi.org/ 10.1016/j.autcon.2018. 11.008

Kaygusuz K. (2009), Energy and environmental issues relating to greenhouse gas emissions for sustainable development in Turkey. Renewable \& Sustainable Energy Reviews, 13, 253-270. DOI: https:// doi.org/ 10.1016/j.rser.2007.07.009

Khaddaj M., Srour I. (2016). Using BIM to Retrofit Existing Buildings. Procedia Engineering, 145, 15261533. DOI: https://doi.org/10.1016/j.proeng.2016.04. 192

Kim S., Zadeh P. A., Staub-French S., Froese T., Cavka B. T. (2016), Assessment of the Impact of Window Size, Position and Orientation on Building Energy Load Using BIM. Procedia Engineering, 145, 1424- 1431. DOI: https:// doi.org/ 10.1016/j.proeng. 2016.04.179

Kullman M., Campillo J., Dahlquist E., Fertner C., Grosse J., Groth N. B., ... Haselberger J. (2016), Note: The PLEEC Project - Planning for Energy Efficient Cities. Journal of Settlements and Spatial Planning, 5, 89-92. DOI:https:// doi.org / 10.19188/ 09J SSPSI052016

Kurian C. P., Milhoutra S., George V. I. (2016), Sustainable building design based on building information modeling (BIM). 2016 IEEE International Conference on Power System Technology, POWERCON 2016. DOI:https:// doi.org/ 10.1109/ POWERCON.2016. 7754039

Li Z., Han Y., Xu P. (2012), Quantitative energy performance assessment methods for existing buildings. Energy and Buildings, 55, 873-888. DOI: https:// doi.org/ 10.1016/j.enbuild.2012.08.037

Lin P. H., Chang C. C., Lin Y. H., Lin W. L. (2019), Green BIM assessment applying for energy consumption and comfort in the traditional public market: A case study. Sustainability (Switzerland), 48
11(17), 4636. DOI: https:// doi.org/ 10.3390/ su11174636 Meng X., Huang Y., Cao Y., Gao Y., Hou C., Zhang L., Shen Q. (2018), Optimization of the wall thermal insulation characteristics based on the intermittent heating operation. Case Studies in Construction Materials, 9, e00188. DOI:https://doi. org/ 10.1016/j.cscm.2018.e00188

Migilinskas D., Popov V., J uocevicius V., Ustinovichius L. (2013). The Benefits, Obstacles and Problems of Practical Bim Implementation. Procedia Engineering, 57, 767-774. DOI:https://doi.org/ 10. 1016/j.proeng.2013.04.097

Nemati B., Zandi S., Aminnejad B., Davarazar M. (2020), Building Information Modelling Execution in Administrative and Commercial Spaces in Iran - A Fuzzy-Delphi Criteria Prioritization. Journal of Settlements and Spatial Planning, 6, 17-27. DOI:https:/ / doi.org/ 10.24193/J SSPSI.2020.6.03

Omer A. M. (2008). Energy, environment and sustainable development. Renewable \& Sustainable Energy Reviews, 12, 2265- 2300. DOI: https:// doi.org/ 10.1016/j.rser.2007.05.001

Pérez-Lombard L., Ortiz J., Pout C. (2008), A review on buildings energy consumption information. Energy and Buildings, 40(3), 394-398. DOI: https:/ / doi.org/ 10.1016/j.enbuild.2007.03.007

Piselli C., Pisello A. L., Saffari M., de Gracia A., Cotana F., Cabeza L. F. (2019), Cool roof impact on building energy need: The role of thermal insulation with varying climate conditions. Energies, 12(17). DOI: https:// doi.org/ 10.3390/ en12173354

Providakis S., Rogers C. D. F., Chapman D. N. (2019), Predictions of settlement risk induced by tunnelling using BIM and 3D visualization tools. Tunnelling and Underground Space Technology, 92(J anuary), 103049. DOI: https://doi.org/ 10.1016/ j.tust.2019.103049

Pruvost H., Scherer R. J. (2017), Analysis of risk in building life cycle coupling BIM-based energy simulation and semantic modeling. Procedia Engineering, 196(J une), 1106-1113. DOI: https:/ / doi.org/ 10.1016/j.proeng.2017.08.068

Reizgevǐcius M., Ustinovǐcius L. (2018), Promoting Sustainability through Investment in Building Information Modeling (BIM) Technologies: A Design Company Perspective. Medizinrecht, 29(4), 122. DOI: https:// doi.org/ 10.3390/ su10030600

Roth K. W., Goldstein F., Kleinman J. (2002), Energy Consumption by Office and Telecommunications Equipment in Commercial Buildings Volume I: Energy Consumption Baseline Prepared by.

Kaneta T., Furusaka S., Deng N. (2017), Overview and problems of BIM implementation in Japan. Frontiers of Engineering Management, 4(2), 146- 155. DOI: https:// doi.org/ 10.15302/J-FEM-2017007

Ugliotti F. M., Dellosta M., Osello A. (2016), BIM- 
Applicability of Building Information Modelling (BIM) in the Sustainable Design of Commercial and Office Buildings.

A Case Study from Tehran, Iran

J ournal of Settlements and Spatial Planning, Special Issue, no. 6 (2020) 41-49

Multi-Criteria Spatial Decision Support Systems for Sustainable Development

based Energy Analysis Using Edilclima EC770 Plug-in, Case Study Archimede Library EEB Project. Procedia Engineering, 161, 3- 8. DOI: https://doi.org/ 10.1016/ j.proeng.2016.08.489

Wi S., Yang S., Berardi U., Kim S. (2019), Assessment of recycled ceramic-based inorganic insulation for improving energy efficiency and flame retardancy of buildings. Environment International, 130 (June), 104900. DOI: https:// doi.org/ 10.1016/ j.envint.2019.06.010

Zandi S., Nemati B., Jahanianfard D., Davarazar M., Sheikhnejad Y., Mostafaie A., ... Aminabhavi, T. M. (2019), Industrial biowastes treatment using membrane bioreactors ( MBRs ) -a scientometric study. Journal of Environmental Management, 247 (February), 462-473. DOI: https:// doi.org/ 10.1016/j.jenvman.2019.06.066

Zardo P., Ribeiro L. A., Mussi A. Q. (2019), Bim and parametric design applications for buildings' energy efficiency: An analysis of practical applications. Arquiteturarevista, 15(2), 238-255. DOI: https:// doi.org/ 10.4013/ arq.2019.152.02

Zhao L., Zhai S., Chen F., Ji F. (2017), Research on the Application of BIM Technology in Tunnel Project Construction. Proceedings of the 20th International Symposium on Advancement of Construction Management and Real Estate, 153, 391-404. DOI: https:// doi.org/ 10.1007/978-981-10-0855-9_34 